\title{
Isolation, screening and characterization of lipase from bacterial isolates and its application in detergents and oily waste water degradation
}

Sadia Faiz ${ }^{1}$, Zahida Nasreen ${ }^{1}$, Aneela Sharif ${ }^{1 *}$ and Saira Naz ${ }^{1}$

1. Department of Zoology, University of Mianwali-Pakistan

*Corresponding author's email: aneelasharif111@gmail.com

Citation

Sadia Faiz, Zahida Nasreen, Aneela Sharif and Saira Naz. Isolation, screening and characterization of lipase from bacterial isolates and its application in detergents and oily waste water degradation. Pure and Applied Biology. Vol. 10, Issue 1, pp209-224. http://dx.doi.org/10.19045/bspab.2021.100022

\begin{tabular}{llll}
\hline \hline Received: 05/06/2020 & Revised: 24/08/2020 & Accepted: 04/09/2020 & Online First: 16/09/2020 \\
\hline \hline
\end{tabular}

\section{Abstract}

The present study was conducted to explore industrial potential of bacterial lipase. Seven isolates were isolated from oil contaminated soil samples. Isolated lipolytic bacteria were grown on lipolytic specific media comprising 1\% (w/v) mustard oil. Egg-yolk test was carried out to determine primary lipase activity. The crude enzyme extracts of two isolates SI1 and S17 showing maximum lipolytic activity were prepared and applied for further practical applications. In oil displacement test, the isolated strains displaced oil (engine oil, vegetable oil, mustard oil, olive oil and crude oil) and exhibited maximum zones of displacement. Lipase was stable in different detergents. Optimum $\mathrm{pH}$ was found to be 8.5 (SI1) and 8.0 (SI7). Optimum temperature for SI1 and SI7 was recorded to be $60^{\circ} \mathrm{C}$ and $40^{\circ} \mathrm{C}$, respectively. Ca2+ enhanced activity of lipase. The activities of SI1 and SI7 lipase was increased by Sodium dodecyl sulphate (5\%) while Tween-80 and Tween-20 negatively affected enzyme activity. Oil Biodegradation activity of isolated lipolytic strains in synthetic and real wastewater was estimated as well as oily stains removal from cotton cloth pieces by crude enzyme extract was carried out. The strains exhibited high efficiency in degrading oily waste water making these strains important from industrial point of view for application in wastewater degradation. Enzyme extract of these isolates also exhibited excellent oily stains removal performance, proving their efficiency to be applied as detergent additives.

Keywords: Applications; Hydrolysis of Oils; Lipolytic bacteria; Oily wastewater

Introduction

Lipases also known as Triacylglycerol hydrolases are capable to perform hydrolysis of triaclyglycerols by converting them into free fatty acids, monoglyceroid, diglyceroid and partial acylglycerols. Lipases are the most flexible biocatalyst which brings about large variety of bioconversion reactions, such as hydrolysis, esterification, acidolysis and aminolysis [1]. These are insidious enzymes which are widely present in animals, plants, fungi and bacteria, having considerable physiological importance and industrial potential [2]. Among these, microbial lipases, particularly from bacteria, have considerable advantages over those 
obtained from plants and animals because of numerous vital characteristics. Many microbes belonging to Acinetobacter, Bacillus, Burkholderia, Idiomarina, Natronococcus, Pseudomonas and Staphylococcus genera have been described to have lipolytic activity [3].

Lipases obtained from microbes have particular aspects such as increased yield, cheap production, varied activities in term of reaction catalyzed, easy genetic manipulation or treatment, stable in presence of different organic solvents and wide substrate specificity due to which these can be applied in wide range of industrial application such as detergent industry and fatty waste water management [4].

It has been estimated that about 13 billion tons of detergents are using about 1000 tons of lipase enzymes annually. The practice of using lipases as detergent additives decrease the need of using synthetic detergents and increases the capability of household detergents to remove tough oily or greasy stains from clothes [5]. Lipases can be utilized efficiently as detergent additives due to their property of hydrolyzing lipids. Lipases are particularly applied in detergents because of their possession of following qualities: (1) Ability to catalyze fats in different combinations (2) capability to survive in comparatively harsh washing environment ( $\left.\mathrm{pH} \quad 10-11,30-60^{\circ} \mathrm{C}\right)$; (3) being able to retain activity in presence of other destructive enzymes, surfactants and inhibitors, which are significant components of many detergent preparations [6].

Lipids (fats, oils and greases) are widely used organic matters in industrial processes and can form layer on the surface of water thereby diminishing oxygen supply rate so industrial and household wastewater containing oily contents can cause environmental issues, therefore their high concentration in wastewater can cause troubles in wastewater treatment processes [7].

Lipases are specifically engaged in wastewater treatment (decreasing lipid congested drains), pharmaceutical, dairy industry, leather (remove fats from skin), detergent (removal of oily stains) and medical (as diagnostic tool) industries [8]. Due to its ability to remove fatty residues and cleaning congested drains, lipases have huge applications in household and industrial laundry detergents [9]. Application of enzymes enhances washing efficacy, thus causing reduction in agitation period, frequently after a first round of soaking [10]. If lipase-producing bacteria are added into the treatment processes, the efficiency of oily wastewater treatment units can be increased. Penicillium, Yarrowia, Geotrichum, Bacillus, Acinetobacter and Serratia spp. are some of microbes, which are being widely used oily wastewaters treatment due to their lipolytic activity[11]. Different bacterial species are applied in bioremediation of crude oil especially Pseudomonas sp. which clean soil from this oil and thus play central role in biodegradation of crude oil [12]. In this context, present study was aimed to find out some of the wide industrial potential of bacterial lipase in order to further explore microbial world for human benefits.

\section{Material and Methods \\ Sample collection}

Soil samples were collected from two locations. One sample was collected from oil and diesel contaminated soil of auto mechanic workshop and second sample was collected from kitchen waste, Mianwali, Pakistan. Each soil sample brought into the laboratory was labeled as S1 and S2 respectively and was further processed.

\section{Isolation of lipolytic bacteria}

Soil samples were diluted by using serial dilution method. Specific lipolytic media having following composition was prepared: 
Peptone Agar 2.9\% (w/v), Yeast Extract $0.3 \%$ (w/v), Mustard Oil 1\% (w/v), pH 7.0. The media was sterilized in autoclave for 15 minutes at $121^{\circ} \mathrm{C}$. After sterilization, media was poured in sterilized petri dishes. After solidification, 10ul of each dilution was spread on solidified media evenly by rotating spreader carefully, following spread plate method. These plates were incubated for 48 hours for isolation of lipolytic bacteria from different soil samples [13].

\section{Pure culturing}

After 48 hours of incubation, lipolytic bacteria were identified by clear zone around colony. Seven isolates were identified (labeled as SI1, SI2, SI3, SI4, SI5, SI6, SI7). After that, isolates were repeatedly grown on specific media to get pure culture. Incubation was done at $37^{\circ} \mathrm{C}$ for 24 to 48 hours.

Egg-yolk test for primary lipolytic activity

The nutrient agar was melted, cooled to $55^{\circ} \mathrm{C}$ and yolk suspension was added to prepare egg yolk testing media. The saturated copper sulphate $(\mathrm{CuSO} 4)$ was added after incubating plates for two days, and kept them for 20 mins. After that, he excess $\mathrm{CuSO} 4$ solution was removed and the plates were kept in incubator for drying. The lipolysis was confirmed by appearance of greenish-blue color of copper soaps of fats [14].

\section{Lipase production}

The basal salt media was prepared for inoculation of lipolytic bacteria having following components: $10 \%$ $\mathrm{Na} 2 \mathrm{HPO} 4.7 \mathrm{H} 2 \mathrm{O} \quad(\mathrm{w} / \mathrm{v}), 2.5 \% \quad \mathrm{KH} 2 \mathrm{PO} 4$ (w/v), $0.6 \% \mathrm{NaCl}, 3 \mathrm{Mm} \mathrm{MgSO} 4.7 \mathrm{H} 2 \mathrm{O}, 1$ $\% \mathrm{NH} 4 \mathrm{Cl}(\mathrm{w} / \mathrm{v}), 2.5 \%$ Glucose) (w/v) with $2.5 \%$ additional Olive oil substrate $(\mathrm{v} / \mathrm{v})$.The $\mathrm{pH}$ of media was kept 7 and then incubation was done at $37^{\circ} \mathrm{C} 24-48 \mathrm{hrs}$ [15].

\section{Preparation of crude lipase}

$24 \mathrm{hrs}$ old culture was used to prepare inoculum by transferring loopful of cells into production media and the flasks were foe $24 \mathrm{hr}$ at $30^{\circ} \mathrm{C}$ in shaker incubator at a rate of 100 r.p.m for lipase synthesis. The crude enzyme were extracted from media by centrifugation at 12000 r.p.m and supernatant was obtained. Further studies of crude enzyme were carried out.

\section{Growth on low cost media}

All seven isolates were grown on two low cost media M1 and M2 (Table 1). Media were prepared, sterilized and all isolates were streaked to check their growth on low cost media.

Table 1. Components of Media M1 and M2

\begin{tabular}{|cc|cc|}
\hline \multicolumn{2}{|c|}{ Composition of M1 media (100ml) } & \multicolumn{2}{c|}{ Composition of M2 media (100ml0 } \\
\hline Wheat brawn $4 \mathrm{~g}$ & Cotton oil cake $4 \mathrm{~g}$ \\
Agar & $2 \mathrm{~g}$ & Agar & $2 \mathrm{~g}$ \\
\hline
\end{tabular}

\section{Morphological examination}

Size, shape, margin, elevation, surface texture (consistency), optical features, and color of the bacterial colonies were noted down on both specific media and nutrient agar plate.

\section{Lipase assay method}

Titrimetric method was used for lipase assay with olive oil serving as a substrate on the basis of hydrolysis of olive oil as it is widely used method for detecting lipase activity due to its ease, accurateness and reproducibility [16]. Culture supernatant $(1 \mathrm{ml})$ was added into reaction mixture having $0.1 \mathrm{M}$ Tris $\mathrm{HCl}$ buffer ( $1 \mathrm{ml}), 3 \mathrm{ml}$ distilled water and olive oil $(3 \mathrm{ml})$ and incubation was done for 24 hours at $37^{\circ} \mathrm{C}$. After that, reaction was stopped by adding $95 \%$ ethanol $(3 \mathrm{ml})$. The titration of released fatty acids was done with $0.1 \mathrm{M} \mathrm{NaOH}$ using $0.1 \%$ alcoholic 
phenolphthalein as indicator until pink color appeared $[17,18]$.

One unit of lipase activity $(\mu \mathrm{g} / \mathrm{ml} / \mathrm{min})$ can be described as the amount of enzyme liberating 1 mole of free fatty acids in a period of $1 \mathrm{~min}$ [15].

\section{Activity of lipase $=\underline{\text { Volume consumed of alkali* }}$ NaOH Normality Incubation time* Volume of Enzyme solution}

\section{Oil displacement test}

To determine lipase activity, oil displacement test was done [7]. For extraction of crude lipase enzyme extract, $100 \mathrm{ml}$ of broth culture was prepared for each isolate (peptone $0.3 \mathrm{~g}$, yeast extract $0.1 \mathrm{~g}$, Sodium Chloride $0.05 \mathrm{~g}$, tween $800.5 \mathrm{~g}$ per $100 \mathrm{ml}$ ), and then sterilization was carried out for 15 minutes at $121^{\circ} \mathrm{C}$. After cooling, media was Inoculated with isolates and incubated at $30^{\circ} \mathrm{C}$ for 72 hours. The culture was then subjected to centrifugation at $7000 \mathrm{rpm}$ for 30 minutes and the crude enzyme extract (supernatant) was collected.

Petri dishes $(150 \mathrm{~mm}$ diameter) were filled with $40 \mathrm{ml}$ of distilled water and then $10 \mathrm{ul}$ of five different oils (weathered hydrocarbons) was added such as engine oil, vegetable oil, mustard oil, mobile oil and olive oil. Then 10ul of cell free culture supernatant of each isolate was placed on the center of each type of oil films. Diameter of clear halo zone was measured, after $30 \mathrm{sec}$ of incubation and readings were noted in triplicates.

\section{Characterization studies of lipase} pH effect on lipase activity

The $\mathrm{pH}$ range of 4 to 11 was selected to detect optimum $\mathrm{pH}$ where enzymes exhibit maximum activities. Citrate phosphate buffer (4.0 7.0), Glycine- $\mathrm{NaOH}$ buffer (7.0 9.0) and Tris- $\mathrm{HCl}$ buffers $(9.0$ 11.0) were used for $\mathrm{pH}$ adjustments.

\section{Temperature effect on enzymatic activities}

To study temperature effect on lipase activity, the activity assay was conducted at temperature range of 20 to $70^{\circ} \mathrm{C}$ to find out temperature for maximum enzyme activity.

\section{Effects of commercial detergents on lipase activity}

The compatibility of lipase in presence of detergents (Ariel, Bright, surf excel, Bonus, Tide, Sufi, Express power) was assayed by adding these at a concentration of $7 \mathrm{mg} / \mathrm{mL}$ in reaction mixture to find out relative activity $(\%)$. The diluted detergents were heated for 40 minutes $60 \circ \mathrm{C}$ to inactivate lipases already present detergents before adding enzyme preparation. The enzyme sample $(40 \mathrm{U} / \mathrm{mL})$ aliquot was subjected to incubation with detergent solution in Tris$\mathrm{HCl}$ buffer for 1 hour at $37^{\circ} \mathrm{C}$ to determine enzyme stability and activity. The relative activity (\%) was recorded and comparison was done with enzyme sample without detergent (control). The activity of enzyme studied without detergent, incubated by having similar conditions was defined as relative activity of control and it was taken as $100 \%$.

Determination of Lipase activity in presence of metal ions, surfactants and inhibitors

The lipase activity in presence of metal ions such $\mathrm{Ca} 2+, \mathrm{Mg} 2+, \mathrm{Zn} 2+, \mathrm{Na}+, \mathrm{Ba}+\mathrm{Li}+$, $\mathrm{K}+(5 \mathrm{Mm}$ Final concentration), surfactants such as Sodium dodecyl sulphate (SDS), Tween 20 , Tween $80,(0.1 \%$ and $0.5 \%$ final concentration) and inhibitors such as Ethylenediaminetetraacetic acid (EDTA) and $\beta$-mercaptoethanol $(1 \mathrm{mM}$ and $5 \mathrm{mM}$ of final concentration) were studied by preincubation of lipase with each of these for 15 minutes. Residual activities were noted down as mentioned above and compared with control. 


\section{Applications}

Application of lipase enzyme extract in removal of oil from synthetic and real waste water

Pure culture of two highly efficient lipolytic isolates (SI1 and SI7) selected from seven isolates on the basis of oil displacement test were applied in the removal of oil from synthetic and real waste water by using method stated by [11].

Media for Inoculum preparation of these two isolates were prepared by adding Yeast extract $0.3 \mathrm{~g}, \mathrm{NaCl} 0.05 \mathrm{~g}$, Tween $800.5 \mathrm{ml}$, in $100 \mathrm{ml}$ of distilled water. After sterilization, media was inoculated with SI1 and SI7 and incubated at $37^{\circ} \mathrm{C}$ for 24 hours.

Synthetic waste water was prepared (Ammonium nitrate $0.4 \mathrm{~g}$, Sodium chloride
$0.5 \mathrm{~g}, \mathrm{KH} 2 \mathrm{PO} 40.2 \mathrm{~g}$ per $100 \mathrm{ml}$ )with various concentration of olive oil $(0.1,1.5$ and $2.0 \mathrm{ml})$.This synthetic waste water and $100 \mathrm{ml}$ of real waste water was sterilized at $121^{\circ} \mathrm{C}$.

$5 \mathrm{ml}$ of inoculum was inoculated in real and synthetic waste water and four readings were taken by titration method at $0,24,48$, and 72 hours of incubation. After this, $10 \mathrm{ml}$ from inoculated real and synthetic wastewater was taken at each intervals of incubation and added $20 \mathrm{ml}$ of acetone: alcohol (1:1) mixture to stop reaction. Than mixture was titrated (Fig. 1) with $0.1 \mathrm{M}$ $\mathrm{NaOH}$ using phenolphthalein indicator, until it got pink color. Noted that point and readings were determined.

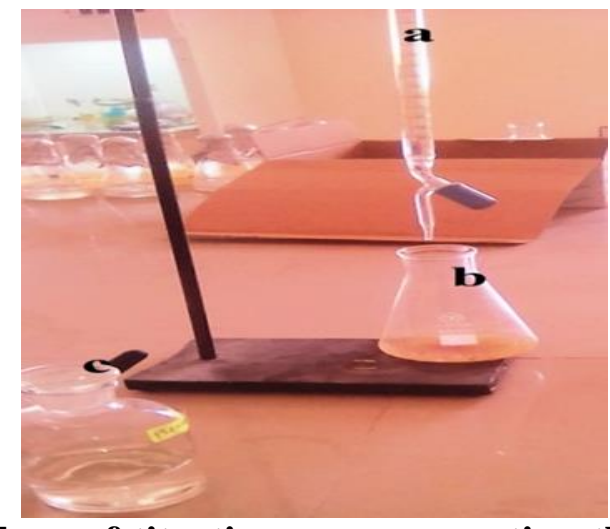

Figure 1. Shows the procedure of titration; a. representing the $0.1 \mathrm{~N} \mathrm{NaOH}$ in burette; $b$. representing the inoculated waste water in flask; c. representing the phenolphthalein indicator

\section{Application of lipase enzyme extract in oily stains removal \\ Application of lipase enzyme extract (for SI1 and SI7)) as a detergent additive was carried out on cotton cloth pieces $(10 \times 10$ $\mathrm{cm})$ blemished with weathered hydrocarbons (olive oil and mustard oil) following method described by [10]. \\ The experimental groups were set to study oily stain removal efficacy of lipase enzyme as follow:}

1. Flask with distilled water $(100 \mathrm{ml})+$ stained cloth (stained with olive and mustard oil).

2. Flask with distilled water $(100 \mathrm{ml})+$ stained cloth (stained with olive and mustard oil) $+1 \mathrm{ml}$ of detergent surf excel $(10 \mathrm{mg} / \mathrm{ml})$.

3. Flask with distilled water $(100 \mathrm{ml})+$ stained cloth (stained with olive and mustard oil $)+1 \mathrm{ml}$ surf excel detergent $(10 \mathrm{mg} / \mathrm{ml})+$ $2 \mathrm{ml}$ of lipase enzyme extract.

All flasks were kept in incubator at $60^{\circ} \mathrm{C}$ for 15 minutes to check oily stain removal 
efficiency. Cloth pieces were visually examined after treatment.

\section{Statistical analysis}

All experiments were performed in triplicates.

Results and Discussion Isolation and morphological examination A total of 7 morphologically distinct colonies were isolated (Fig. 2) by using lipolytic selective agar medium from the soil samples and labeled as SI1, SI2, SI3, SI4, SI5, SI6, and SI7. Analysis of pure colonies of lipolytic bacteria based on morphological characteristics was carried out (Table 2). Growth of each isolated strains on semi solid agar media showed that all strains were motile.
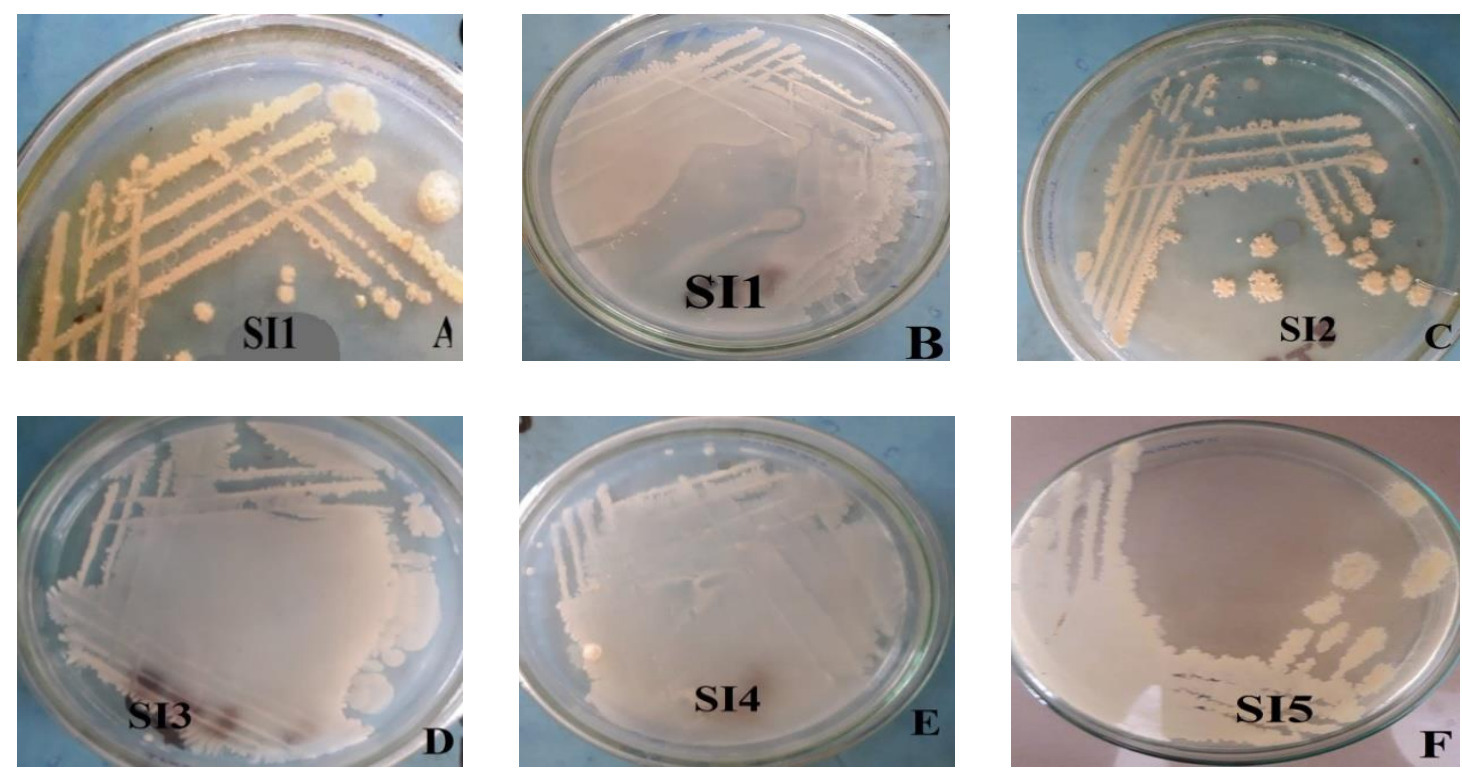

Figure 2. Growth of isolated strains from oily soil sample: (A) growth of SI1 strain on Selective media; (B) SI1 on Nutrient agar media; (C) SI2 on Selective media; (D) SI3 on Nutrient agar media; (E) SI4 on nutrient agar media; (F) SI5 on Selective media

Table 2. Morphological features of seven isolates on both selective and nutrient agar media

\begin{tabular}{|c|c|c|c|c|c|c|c|c|}
\hline Isolates & $\begin{array}{c}\text { Size } \\
\text { (diameter) }\end{array}$ & Margin & Elevation & $\begin{array}{c}\text { Surface } \\
\text { texture }\end{array}$ & $\begin{array}{l}\text { Optical } \\
\text { feature }\end{array}$ & Colour & Shape & Motility \\
\hline SI1* & $9 \mathrm{~mm}$ & lobate & raised & creamy & Opaque & Off white & Irregular & Motile \\
\hline SI1• & $4 \mathrm{~mm}$ & Filliform & raised & Rubbery & Opaque & Off white & Filamentous & Motile \\
\hline SI2* & $6 \mathrm{~mm}$ & Undulate & Convex & Creamy & Opaque & Off white & Irregular & Motile \\
\hline SI2• & $5 \mathrm{~mm}$ & Fibril & Raised & Creamy & Opaque & Off white & Filamentous & Motile \\
\hline SI3* & $1 \mathrm{~cm}$ & Undulate & Flat & Creamy & Opaque & Off white & Irregular & Motile \\
\hline SI3• & $9 \mathrm{~mm}$ & Lobate & Raised & Brittle & Translucent & Off white & Lobate & Motile \\
\hline SI4* & $3 \mathrm{~mm}$ & Undulate & Raised c & Buttery & Opaque & Off white & Undulate & Motile \\
\hline SI4• & $3 \mathrm{~mm}$ & Lobate & Convex & Creamy & Translucent & Off white & Lobate & Motile \\
\hline SI5* & $1 \mathrm{~cm}$ & Undulate & Raised & Creamy & Opaque & Off white & Irregular & Motile \\
\hline SI5• & $5 \mathrm{~mm}$ & Filamentous & Raised & Creamy & Opaque & Off white & Filamentous & motile \\
\hline SI6* & $2 \mathrm{~cm}$ & Filliform & Raised & Creamy & Opaque & Off white & Filliform & motile \\
\hline SI6• & Spreading & Spread & Raised & Brittle & Opaque & Off white & Spreading & motile \\
\hline SI7* & $3 \mathrm{~mm}$ & undulate & Raised & creamy & Opaque & Off white & Undulate & motile \\
\hline
\end{tabular}


Egg-yolk screening test for primary lipolytic activity

The bacterial lipase activity can be detected by using egg-yolk suspension. Lipolysis can be observed by appearance of, shimmering 'pearly layer' covering the colonies and a 'confined' opalescence in the in solid media containing egg yolk suspension. Greenishblue unsolvable copper soaps is formed by reaction of copper sulphate with the fatty acids, visible in both shining layer and opalescence in the media. Lipase destroys the fats within the egg yolk, which results in Greenish blue color of colony appears due to activity of lipase destroying fats of egg yolk of the after addition of copper II sulphate solution.

\section{Growth on low cost media}

On the media M1 and M2, all seven isolates (SI1, SI2, SI3, SI4, SI5, SI6 and SI7) were grown. After incubating for $48 \mathrm{~h}$, the results showed that on M1 media each isolates showed positive growth, but on M2 media SI5 and SI7 showed negative growth, while other SI1, SI2, SI3, SI4, and SI6 gave positive results.

\section{Oil displacement test}

Oil displacement test showed that all seven isolated strains were lipolytic but SI1 and SI7 (Fig. 3, 4, 5) showed increased lipolytic activity and hence these were used for further experiments to check their potential for practical applications [7] Zone of Hydrolysis were measured for all isolates to quantify their lipolytic potential (Table 3).

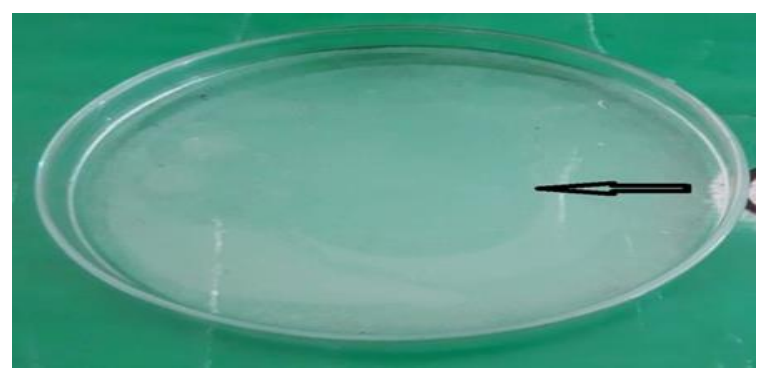

Figure 3. Arrow indicates the clear zone formed by SI1 during oil displacement test

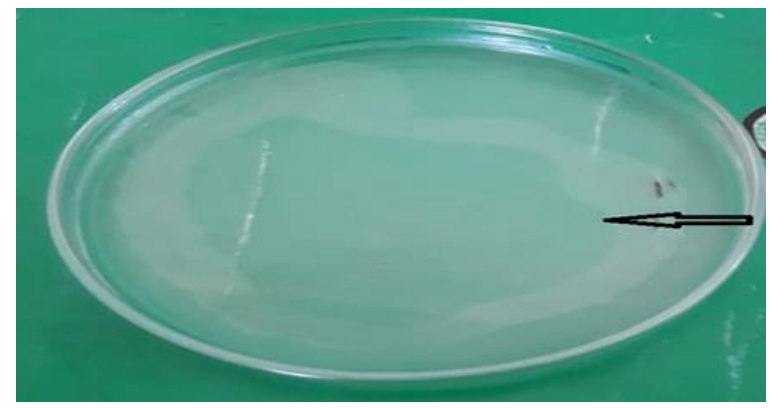

Figure 4. Arrow indicates the clear zone formed by SI7 during oil displacement test

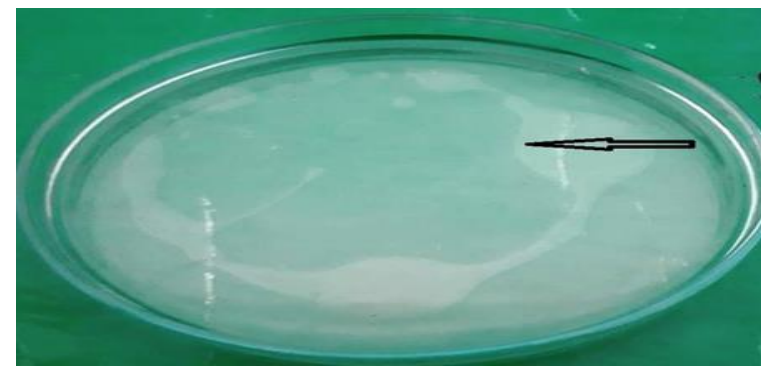

Figure 5. Arrow indicates the clear zone formed by SI3 during oil displacement test 
Table 3. Diameters (in cm) of clear zone formed by seven isolates in oil displacement test

\begin{tabular}{|c|c|c|c|c|c|}
\hline & OI.O & M.O & E.O & V.O & Ms.O \\
\hline SI1 & $5.93 \pm 0.57$ & $6.33 \pm$ & $4.26 \pm$ & $5.26 \pm$ & $4.43 \pm 0.71$ \\
\hline SI2 & $4.70 \pm 0.43$ & $7.33 \pm 0.37$ & $3.46 \pm 0.52$ & $5.23 \pm 0.37$ & $3.40 \pm 0.20$ \\
\hline SI3 & $7.23 \pm 0.43$ & $6.20 \pm 0.15$ & $3.80 \pm 0.11$ & $5.66 \pm 0.44$ & $4.36 \pm 0.48$ \\
\hline SI4 & $4.06 \pm 0.52$ & $5.53 \pm 0.24$ & $3.20 \pm 0.36$ & $5.73 \pm 0.53$ & $4.90 \pm 0.60$ \\
\hline SI5 & $4.06 \pm 0.63$ & $6.50 \pm 0.28$ & $2.73 \pm 0.14$ & $4.83 \pm 0.52$ & $3.93 \pm 0.33$ \\
\hline SI6 & $5.20 \pm 0.30$ & $3.76 \pm 0.14$ & $2.63 \pm 0.18$ & $5.20 \pm 0.89$ & $5.40 \pm 0.41$ \\
\hline SI7 & $6.66 \pm 0.49$ & $4.56 \pm 0.20$ & $3.9 \pm 0.51$ & $5.66 \pm 0.24$ & $4.76 \pm 0.28$ \\
\hline
\end{tabular}

Ol.O (olive oil), M.O (Mobile oil), E.O (Engine oil), V.O (Vegetable oil), Ms. O (Mustard oil).

Data represents Mean \pm Standard error of mean (S.E.M).

\section{pH and temperature effect on lipase activity}

The activity of SI1 and SI7 lipase was observed in $\mathrm{pH}$ range of 4 to 11 (Fig. 6) and optimum $\mathrm{pH}$ was found to be 8.5 and 8.0 , respectively. It was reported that Lipase of Bacillus sp. exhibited maximum activity at pH7.0 [15]. Bacillus methylotropicus lipase was reported to be stable at $\mathrm{p} \mathrm{H} \mathrm{7.0-9.0.}$ [17]. The optimum pH for Serratia sp. (C4) was found to be 8.0 [19]. The optimum $\mathrm{pH}$ for Staphylococcus aureus strain ALA1 lipase was 12.0 and activity was loss by $50 \%$ at $\mathrm{pH} 2.0$ [20]. Bacillus sp. lipase was found to have an optimum $\mathrm{pH}$ of 7.0. [21]. Streptomyces fungicidicus RPBS-A4 lipase was reported to have optimum $\mathrm{pH}$ 9.0. [22]. Optimum $\mathrm{pH}$ for Bacillus coagulans lipase was reported to be 7.0 [23].
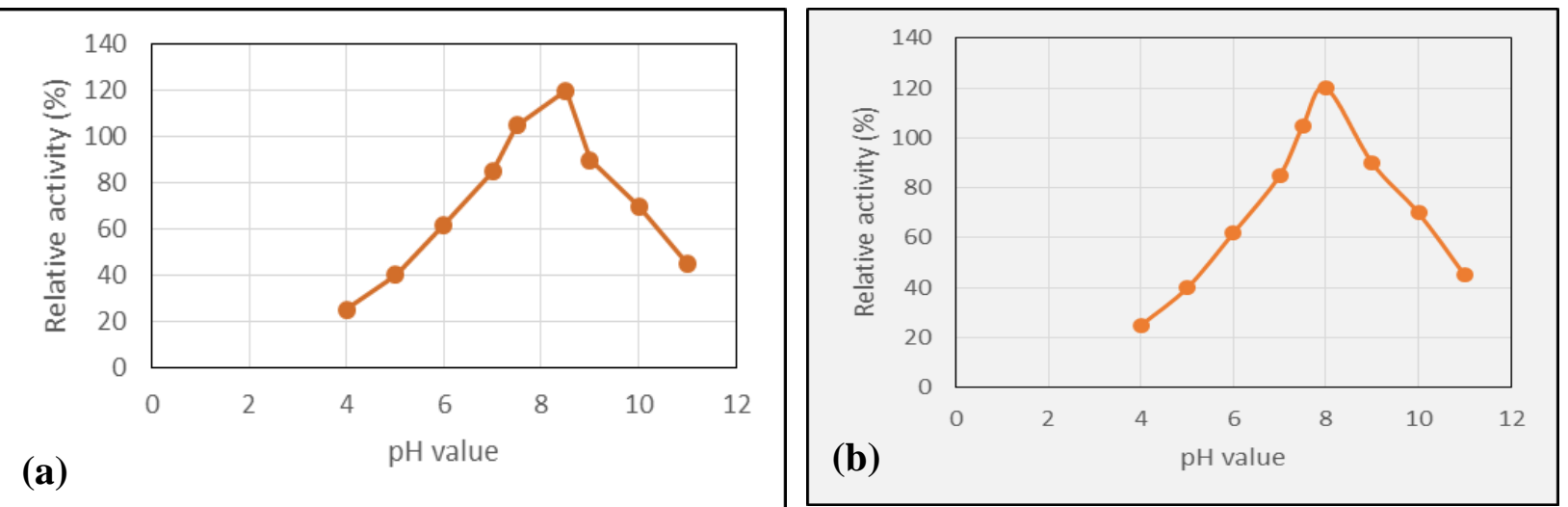

Figure 6. (a) Relative activity (\%) of SD1 at optimum pH; (b) Relative activity of SI7 at optimum pH

The SI1 lipases was found to have optimum activity at $60^{\circ} \mathrm{C}$ while SI7 crude lipase was had showed maximum activity at $40^{\circ} \mathrm{C}$ (Fig. 7). The Bacillus methylotropicus lipase had optimum temperature of $55^{\circ} \mathrm{C}$ [17]. Serratia $s p .(C 4)$ was found to have optimum activity at $30^{\circ} \mathrm{C}$ [19]. Lipases from Staphylococcus aureus strain ALA1 exhibited maximum activity within temperature range of $55^{\circ} \mathrm{C}$ to $60^{\circ} \mathrm{C}$ and loss of activity at $75^{\circ} \mathrm{C}$ was observed [20]. Activity was Bacillus sp. lipase was studied to be maximum at $36^{\circ} \mathrm{C}$ [21]. Streptomyces fungicidicus RPBS-A4 lipase exhibited maximum activity at $40^{\circ} \mathrm{C}$. [22]. 
Bacillus coagulans lipase exhibited an optimum temperature of $50^{\circ} \mathrm{C}$ [23].
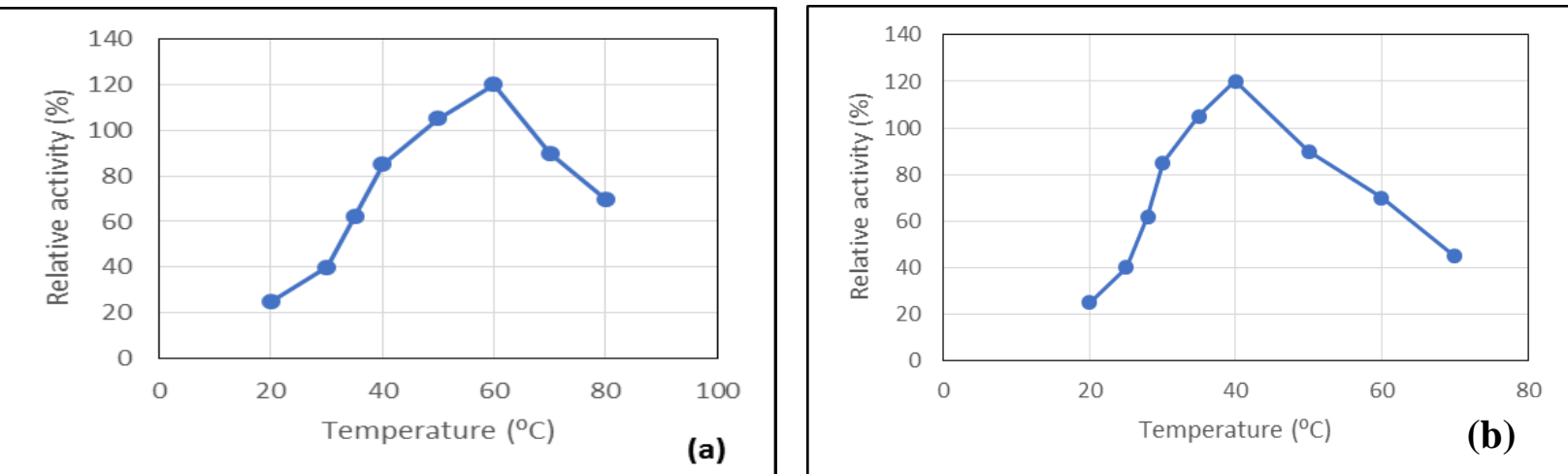

Figure 7. (a) Maximum activity of SI1 lipase at optimum temperature. (b) Maximum activity of SI7 lipase at optimum temperature

Effect of detergents on lipase activity

The effects of different detergent (Ariel, Bright, surf excel, Bonus, Tide, Sufi, Express power) on enzyme activity were studied (Table 4). It was found that the lipases of SI1 and SI7 exhibited negligible loss of activity after being incubated with different commercial detergents. Thus, these novel lipases are stable in presence of detergents as compared to commercially available lipases. Similar results has been described earlier where Staphylococcus aureus were found to be remarkably stable in presence of different commercially available liquid and solid detergents such as Ariel, Dixan, Nadhif and Tide [20]. Streptomyces fungicidicus RPBS-A4 lipase exhibited maximum activity in presence of 'Ariel 'detergent having 96.6\% activity followed by 'Surf excel with $90 \%$ activity [22]. The Bacillus sp. DH4 lipase exhibited stability in presence of various detergents [24]. Bacillus smithi BTMS 11 lipase exhibited $10 \%$ loss of activity in presence of Ariel,, Tide, Surf, and Henko [25].The Staphylococcus sp. ESW was reported to maintain it activity in presence of Ariel, Dixan and Nadhif [26].

Table 4. Effect of Detergents on lipase activity

\begin{tabular}{|c|c|c|}
\hline \multirow{2}{*}{ Detergents (7mg/mL) } & \multicolumn{2}{|c|}{ Relative activity (\%) } \\
\cline { 2 - 3 } & SI1 & SI7 \\
\hline Ariel & $100 \pm 0$ & $65 \pm 3.5$ \\
\hline Bright & $95.5 \pm 2.6$ & $60.2 \pm 5.3$ \\
\hline Surf Excel & $94.5 \pm 2.5$ & $48.3 \pm 4.1$ \\
\hline Bonus & $86.6 \pm 5.5$ & $59.4 \pm 1.5$ \\
\hline Tide & $86.5 \pm 1.4$ & $87.9 \pm 2.5$ \\
\hline Sufi & $81.2 \pm 2.9$ & $83.3 \pm 1.7$ \\
\hline Express Power & $80.5 \pm 1.9$ & $85.2 \pm 2.1$ \\
\hline
\end{tabular}

Values represent mean of three replicates \pm Standard deviation

Lipase activity in presence of metal ions, inhibitors and surfactants

Different metal ions, inhibitors and surfactants were studied to determine activity of lipase (Table 5). The metal ions effect on SI1 lipase are as follow: $\mathrm{K}+, \mathrm{Zn} 2+$ and $\mathrm{Li}+$ slightly decreased the activity of crude lipase while there was no such effect on lipase activity by $\mathrm{Ba}+$ and $\mathrm{Na}+, \mathrm{Mg} 2+$ 
slightly decreased lipase activity while there was $55 \%$ increase in activity by $\mathrm{Ca} 2+$.

The effect of Metal ions on SI7 lipase were recorded to be as follow: $\mathrm{Ba}+, \mathrm{Li}+\mathrm{K}+$, and $\mathrm{Zn} 2+$ Negatively affected activity of lipases, $\mathrm{Ca} 2+$ caused $24 \%$ increase in relative activity of enzyme, $\mathrm{Mg} 2+$ and $\mathrm{Ba}+$ caused no significant loss of activity.

It has been reported earlier that $\mathrm{Ca} 2+$ ions resulted in increased lipase activity. Streptomyces fungicidicus RPBS-A4 lipase was reported to increase in presence of metal ions with maximum relative activity achieved in presence of $\mathrm{CaCl} 2, \mathrm{NaCl}$ and MgSO4 was $103.28 \%, 96.66 \%$, and $93.33 \%$, respectively [22].

The activity of lipase from bacterial isolates maximum was found to be maximum in $\mathrm{Cu} 2+$ and $\mathrm{Mg} 2+$ presence and $\mathrm{Ca} 2+$ had no significant effect on activity of enzyme [27]. The activity of lipase from Staphylococcus $s p$. is dependent on $\mathrm{Ca} 2+$ ions presence [28]. $\mathrm{K}+$ and $\mathrm{Ca}++$ increased activity of Bacillus coagulans Lipase [23].

There was a decrease in lipase activity by $55.3 \%$ by EDTA, while $\beta$-Mercaptoethanol had no such negative effect on lipase activity in case of SI1 while loss of activity of SI7 lipase by EDTA and $\beta$ Mercaptoethanol was recorded to be $49.85 \%, 12.4 \%$, respectively.

The effect of surfactants on lipase activity (Table 6) was studied. The activities of SI1 and SI7 lipase were increased by SDS (5\%) while there was a decreased in enzyme activity in presence of Tween-80 and Tween-20. It has been reported that the Staphylococcus arlettae JPBW-1 lipase is highly compatible and stable in presence of surfactants and commercial detergents. The increase in stability of lipase was observed with SDS and Tween 80 [29].

Table 5. Effect of metal ions on lipase activity

\begin{tabular}{|c|c|c|}
\hline \multirow{2}{*}{ Metal ions (1 mM) } & \multicolumn{2}{|c|}{ Relative activity (\%) } \\
\cline { 2 - 3 } & SI1 & SI7 \\
\hline Control & $100 \pm 2.5$ & $100 \pm 2.1$ \\
\hline $\mathrm{Ca} 2+$ & $155.0 \pm 3.1$ & $124 \pm 1.3$ \\
\hline $\mathrm{Ba}+$ & $97.1 \pm 1.4$ & $80 \pm 3.6$ \\
\hline $\mathrm{Li}+$ & $62.1 \pm 1.25$ & $78.1 \pm 4.01$ \\
\hline $\mathrm{Na}+$ & $99.2 \pm 3.07$ & $96.3 \pm 2.5$ \\
\hline $\mathrm{K}+$ & $79 \pm 0.7$ & $88 \pm 1.8$ \\
\hline $\mathrm{Mg} 2+$ & $86.5 \pm 1.2$ & $90 \pm 3.5$ \\
\hline $\mathrm{Zn} 2+$ & $68 \pm 2.01$ & $77.3 \pm 2.6$ \\
\hline \multicolumn{3}{|c|}{ Inhibitors (1 $\mathbf{~ m M})$} \\
\hline EDTA & $93.2 \pm 4.7$ & $88.6 \pm 2.0$ \\
\hline
\end{tabular}

Values represent mean of three replicates \pm Standard deviation

Table 6. Effect of Surfactants on lipase activity

\begin{tabular}{|c|c|c|c|}
\hline \multirow{2}{*}{ Surfactants } & \multirow{2}{*}{ Final Concentration } & \multicolumn{2}{|c|}{ Relative activity (\%) } \\
\cline { 3 - 4 } & & SI1 & SI7 \\
\hline Control & - & $100 \pm 1.5$ & $100 \pm 2.1$ \\
\hline SDS & $5 \%$ & $105 \pm 2.9$ & $115 \pm 3.5$ \\
\hline Tween 80 & $5 \%$ & $97.2 \pm 3.1$ & $92 \pm 1.7$ \\
\hline Tween 20 & $5 \%$ & $93 \pm 1.2$ & $89.5 \pm 4.2$ \\
\hline
\end{tabular}

Values represent mean of three replicates \pm Standard deviation 
Application of Lipase Enzymes in the removal of oil from synthetic and real waste water

The ability of two isolated strains (SI1 \& SI7) that offered the highest lipolytic activity to degrade oily waste water was assessed. Flasks with synthetic and real waste water were prepared and incubated at $30^{\circ} \mathrm{C}$ and oil removal rate was observed after 24 to $48 \mathrm{hrs}$ of incubation. Titration values recorded at equal interval of time for isolate SI1 and SI7 in synthetic and real waste water are shown (Fig. 8, 9, 10, 11). Ammonium sulfate (NH4SO4) can also be used as a nitrogen source [30]. But Sulfuric acid is produced due to ammonia consumption from ammonium sulfate which can cause reduction in $\mathrm{pH}$, and this change in $\mathrm{pH}$ can diminish the oil degradation activity of bacteria [30].
Both isolates SI1 and SI7 showed positive results when tested for oil-degradation. Hence it is proved that the bacterial isolates obtained from the diesel contaminated soil were oildegrading bacteria.

$30-40 \%$ of lipids are present in municipal waste water as compared to total chemical oxygen demand. Oily wastewaters were conventionally being treated by physical methods, which are currently being considered as inefficient especially if the fat is present in dispersed state. Fat, oil and grease can be degraded into miscible molecules by using biological treatment and thus applying microbes for removing oily wastes is considered the most efficient method. Thus, the usage of microbial lipases may solve the problem [31].

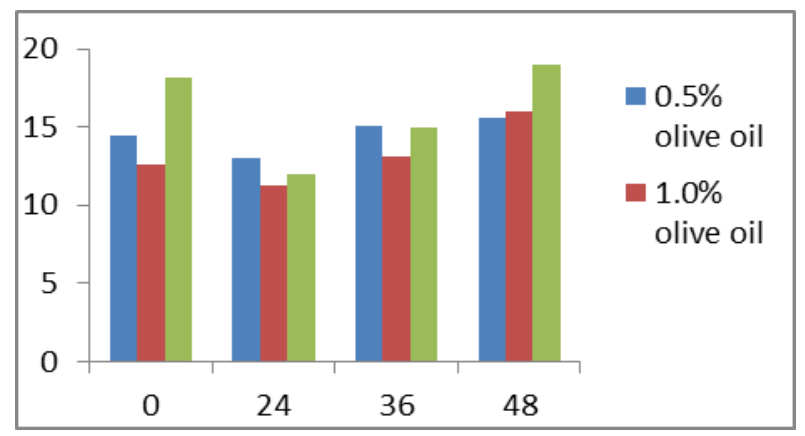

Time $(\mathrm{h}) \rightarrow$

Figure 8. Titration values (for SI1 isolate) at equal intervals of time (24h) with three different concentration of olive oil $\left(0.5\right.$. 1.0, 2.0) in synthetic wastewater, at $30^{\circ} \mathrm{C}$ temperature

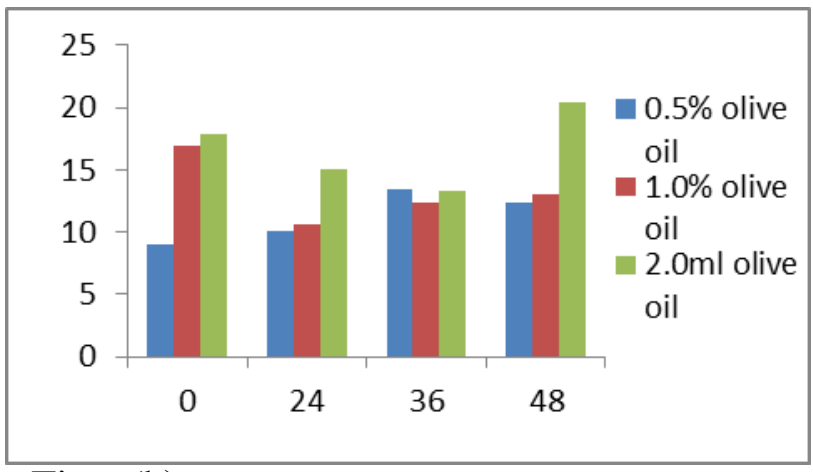

Time $(\mathrm{h}) \rightarrow$

Figure 9. Titration values (for SI7 isolate) at equal intervals of time (24h) with three different concentration of olive oil $(0.5,1.0,2.0)$ in synthetic wastewater, at $30^{\circ} \mathrm{C}$ temperature 


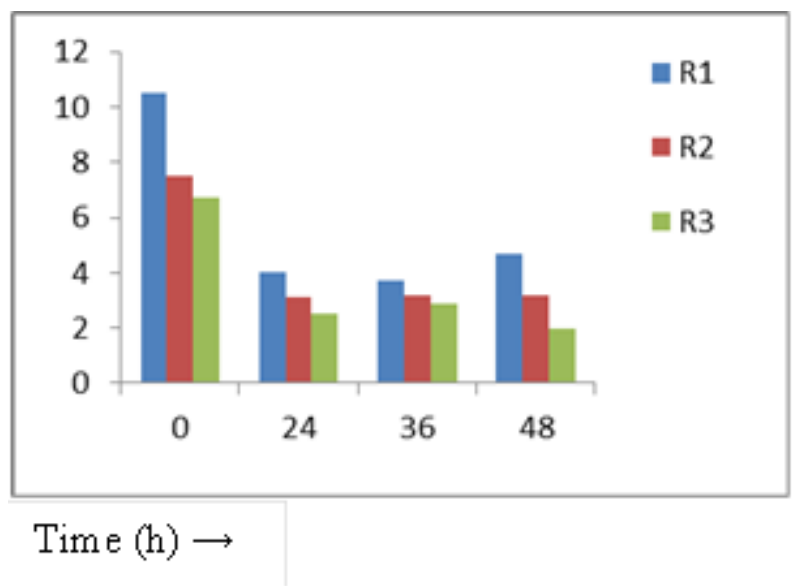

Figure 10. Titration values (for SI1 isolate) at equal intervals of time (24h) in real wastewater, at $30^{\circ} \mathrm{C}$ temperature

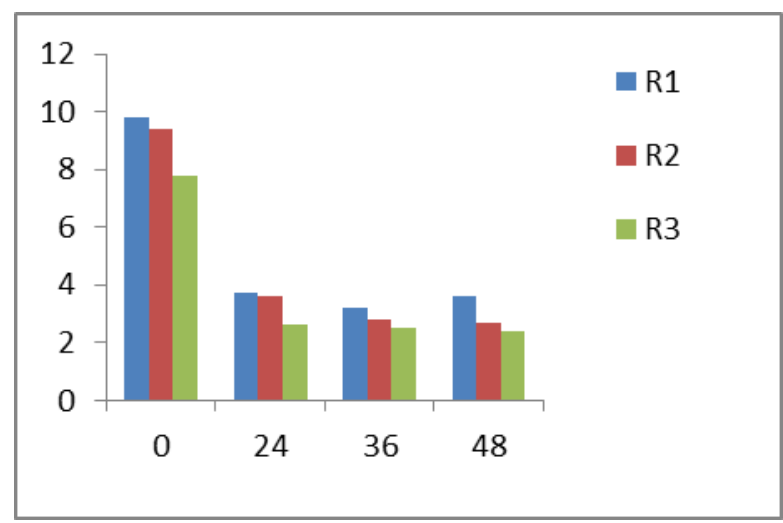

Time $(\mathrm{h}) \rightarrow$

Figure 11. Titration values (for SI7 isolate) at equalin tervals of time (24h) in real wastewater, at $30^{\circ} \mathrm{Ctemperature.}(\mathrm{R} 1, \mathrm{R} 2$ and $\mathrm{R3}=$ real wastewater)

It was evaluated that the application of mixed culture containing Pseudomonas aeruginosa LP602 and Acinetobacter calcoaceticus LP009 (lipase producing bacteria) can decrease the biochemical oxygen demand (BOD) and also lower the concentration of lipids in lipid-loaded effluents [32]. The free and immobilized Yarrowia lipolytica has also been reported to biodegrade oil wastewater. This study proved that immobilized $Y$. lipolytica can be applied for removal of oil from wastewater [11].

Lipase produced by $P$. aeruginosa showed very good results in degradation of oil from palm oil industry effluents, soap effluent and domestic waste water while lipids from Serratia marsescens exhibited good lipolytic activity in dairy effluents and Staphylococcus aureus in slaughter house wastewater [33].
Four bacterial isolates used for treatment of bakery industry wastewater effluent exhibited decrease in grease, fats, oils and Chemical Oxygen Demand after treatments. Isolates also exhibited positive results regarding degradation of palm oil wastes [34].

The commercial microbial supplements were studied to degrade fat/oil. One of the multispecies supplements tested extensively increased biodegradation of fats and oils by $37-62 \%$ [35].

Application of lipase enzyme extract for removal of oily stains from cotton cloth pieces The detergent additives capability of lipases was studied to determine the efficiency of the enzyme to improve wash performance of detergent. The addition of lipase in detergent had significant impact on improvement of the oil stains removal within period of 10 minutes. The 
oily stain was simply removed from cloth (Fig. 12) by incubating them in enzyme extract [10]. It was proved that lipase enzymes obtained from SI1 and SI7 were capable of removing the oily stains from clothes. Incomplete stains removal was observed when clothes were washed only with the water and with water containing detergent, whereas as stains were almost completely removed when lipase enzyme extract was added to remove stains from clothes.

The efficiency of lipase obtained from Bacillus methylotrophicus PS3 to be applied for the removal of grease, butter, vegetable oil, olive oil stains within $30 \mathrm{~min}$ was reported, therefore these can be viewed as important possible candidate as laundry detergent additive. The detergents containing enzymes as detergent additives also have this advantage of fabric quality improvement and no change in color brightness of clothes [17].

The efficient removal of olive oil from clothes by lipase isolated from Bacillus subtilis along with detergent was reported [5]. Compatibility of Staphylococcus aureus strain ALA1 Lipase with different detergents was investigated. Surprisingly, the isolated enzyme showed more stability than the currently used lipases with all detergents tested [20].

Staphylococcus arlettae JPBW-1 lipase was evaluated for its oily stain removal capability for application of lipase as an laundry detergent additive. The $0.5 \%$ wheel detergent along with supplementation of lipase resulted in maximum oil removal (62\%) from the oiled cloth [29].

The enzyme lipase was applied effectively and safely on the archeological textiles to remove the oily dirt which is difficult to be removed by traditional methods [36]. It was reported that lipase from Streptomyces fungicidicus RPBS-A4 was suitable to be applied as detergent additive along with many commercially available detergents such as Ariel, Surf excel, Tide, Wheel etc. to remove oil based stains from clothes [22].
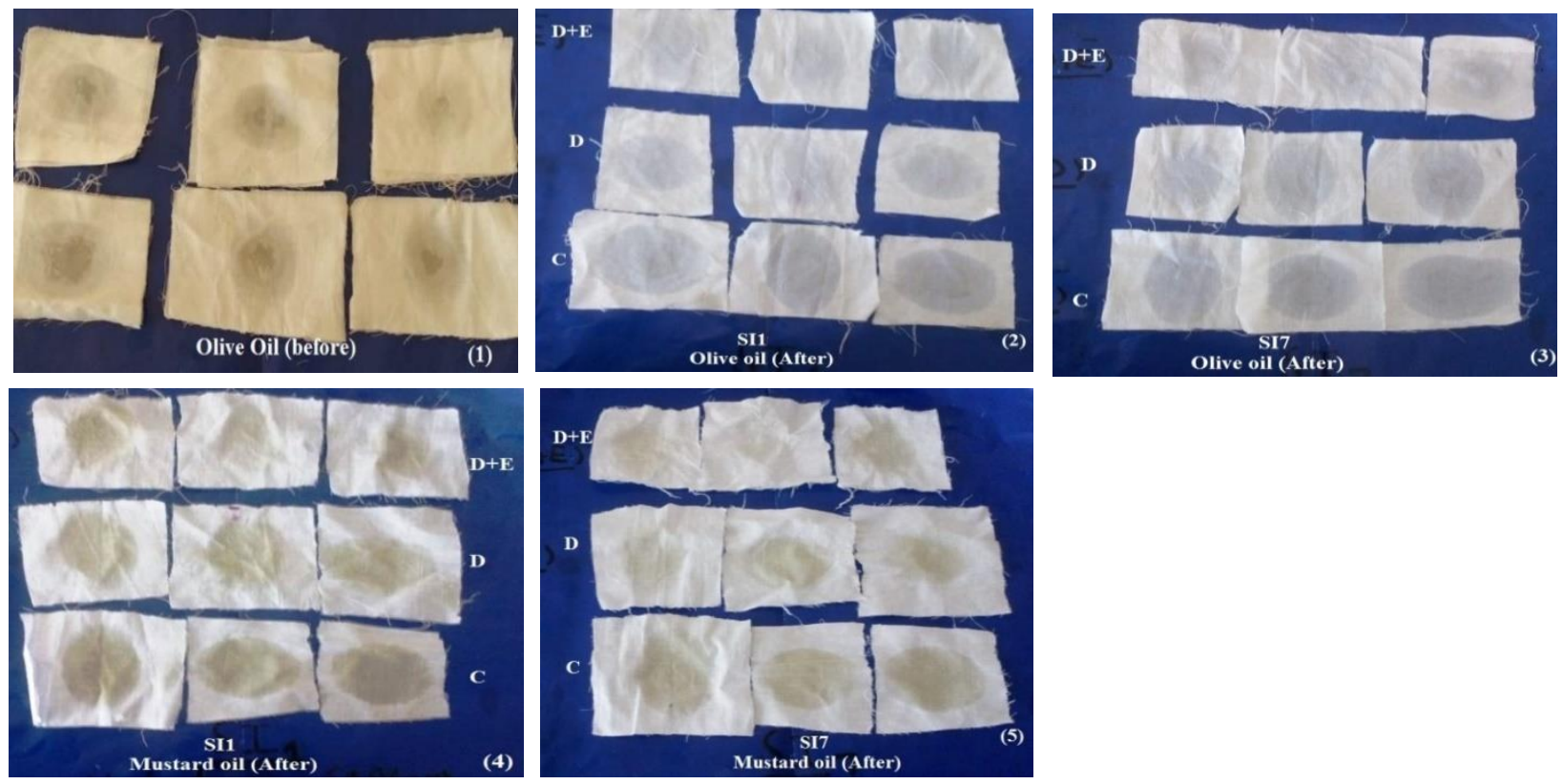

Figure 12. Washing performance of lipase enzymes: (1) cloth stained with olive oil before incubation; (2) olive oil stained cloth washed with distilled water only $(C)$, with detergent (D), and with detergent and SI1 lipase enzyme extract (D+E); (3) olive oil stained cloth washed with distilled water only (C), with detergent (D), and with detergent and SI7 lipase enzyme extract (D+E); (4) mustard oil stained cloth washed with distilled water only (C), with detergent (D), and with detergent and SI1 lipase enzyme extract (D+E); (5) mustard oil stained cloth washed with distilled water only (C), with detergent (D), and with detergent and SI7 enzyme extract (D+E) 


\section{Conclusion}

The present work was aimed to isolate and characterize lipolytic strains from various soil samples. Seven bacterial isolates were isolated on medium containing lipid as a sole source of carbon and zone of hydrolysis was observed. On screening, isolates having highest lipolytic activity were selected, and further studied. The methods of choice were selected based upon the purpose of study and the available laboratory equipment. The results of the research reported that isolates which were obtained from the diesel contamoinated soil and kitchen waste, can degrade the oil and lipids.Therefore, these strains can be applied for remediation of oily wastewater in biological treatment processes. as well as can be used as detergent additives for removal of oily stains. It is predictable that the findings of current study can be exploited for future studies, and the lipase producing bacteria isolated from diesel and kitchen wastes will help in future, as possible solution for combating environmental pollution arising due to industrial and household effluents and wastewater. The tremendous potential of lipases in degradation of oil will be helpful in future to develop new, cost-effective and environmentally friendly technologies for increased production, scaling up and purification of this useful enzyme.

\section{Authors' contributions}

Conceived and designed the experiments: $\mathrm{Z}$ Nasreen \& S Fiaz, Performed the experiments: S Fiaz \& Z Nasreen, Analyzed the data: A Sharif, Contributed materials/ analysis/ tools: S Naz, Wrote the paper: S Faiz \& A Sharif.

\section{References}

1. Zaliha RN, Rahman RA, Baharum SN, Basri M \& Salleh AB (2005). High yield purifcation of an organic solventtolerant lipase from Pseudomonas sp. Anal Biochem 341: 267-274.
2. Rajendran A, Palanisamy A \& Thangavelu V (2007). Lipase applications in food industry. Indian $J$ Biotech 6: 141-158.

3. Daroonpunt R, Tanaka N, Uchino M \& Tanasupawat S (2008).Characterization and screening of lipolytic bacteria from Thai fermented Fish. Sains Malay 47(1): 91-97.

4. Glogauer A, Martini VP, Faoro H, Couto GH, Santos MM, Monteiro RA, Mitchell DA, Souza EM, Pedrosa FO \& Krieger N (2011). Identification and characterization of a new true lipase isolated through metagenomic approach. Microb Cell Fact 10: 1-54.

5. Saraswat R, Verma V, Sistla S \& Bhushan I (2017). Evaluation of alkali and thermotolerant lipase from an indigenous isolated Bacillus strain for detergent formulation. Electron $J$ Biotech 30: 33-38.

6. Sharma R, Chisti Y \& Banerjee UC (2001). Production, purification, characterization and applications of lipases. Biotechnol Adv 19: 627-662.

7. Abbas H, Wsain SM, AL-Quraishi DA \& Fartoos SK (2015). Using of biosurfactant and bacterial enzymes for treatment of the oily polluted soils. Int $J$ Adv Res 3(5): 741-748.

8. Verma $S$ \& Sharma $P$ (2014). Isolation, Identification and characterization of Lipase producing Microorganisms from environment. Asian J Pharm Clin Res 7(4): 219-222.

9. Hasan F, Shah AA, Javed S \& Hameed A (2010). Enzymes used in detergents: Lipases. Afr J Biotechnol 9(31): 48364844.

10. Kanmani R, Dhivya S, Jayalakshmi \& Vijayabaskar P (2011). Studies on detergent additives of protease enzyme from an estuarine bacterium Bacillus cereus. Int Res J Biotechnol 2 (7): 157163. 
11. Azhdarpoor A, Mortazavi B \& Moussavi G (2014). Oily wastewaters treatment using Pseudomonas sp. Isolated from the compost fertilizer. $J$ Environ Health Sci Eng 12:77.

12. Ghafil JA, Hassan SS \& Zgair AK (2016).Use of immobilized lipase in cleaning up soil contaminated with oil. World J Exp Biosci 4(1): 53-57.

13. Sirisha E, Rajasekar N \& Narasu ML (2010). Isolation and Optimization of Lipase Producing Bacteria from Oil Contaminated Soils. Adv Biol Res 4 (5): 249-252.

14. Wai KP, Oo WWN \& Shwe MT (2016). Screening on Lipase-producing Bacteria Isolated from Oil Mill Soil. 5th International Conference on Food, Agricultural and Biological Sciences (ICFABS-2016) Dec. 25-26， 2016 Bangkok (Thailand).

15. Kandala H, Roy D, Sathiavelu M, Arunachalam S \& Loganathan K (2010). Isolation And Characterization Of Lipase Producing Bacteria From Vellore Soil. Pharmacology online 2: 356-361

16. Aravindan R, Anbumathi $P$ \&Viruthagiri $\mathrm{T}$ (2007). Lipase applications in food industry. Indian $J$ Biotech 6: 141-158.

17. Sharma P, Sharma N, Pathania S \& Hande S (2017).Purification and characterization of lipase from Bacillus methylotrophicus PS3 under submerged fermentation and its application in detergent industry. $J$ Genet Eng Biotechnol 15:369-377.

18. Ugochukwu C, Agha NC \& Ogbulie JN (2008). Lipase Activities Of Microbial Isolates From Soil Contaminated With Crude Oil After Bioremediation. Afr J Biotechnol 7 (16): 2881-2884.

19. Ray S (2012). Fermentative production of an alkaline extracellular lipase using an isolated bacterial strain of Serratia $\mathrm{sp}$

\section{(C4). J Microbiol Biotech Res 2 (4):545-557.}

20. Bacha AB, Al-Assaf A, Moubayed N \& Abid I (2018). Evaluation of novel thermo-alkaline Staphylococcus aureus lipase for application in detergent formulations. Saudi J Biol Sci 25: 409417.

21. Kalapatapu VP \& Reddy IB (2015). A Study Of Thermostable And Uv Resistant Lipase Producing Bacillus Species. Int J Adv Res 3(3):1-19.

22. Rajanikanth A \& Damodharam $T$ (2017).Partial Purification And Characterization Of Detergent Compatible Lipase From Marine Sterptomyces Fungicidicus RPBS-A4 For Application In Oil Based stain Removal. Int J Curr Adv Res 6(6):43454351.

23. Alya MM, Ha Al-Shareef HAA, Quria HA \& Al-seeni MN (2017). Spore Forming Bacterium from Oil Contaminated Soil as a Source of a Lipase Enzyme with Exogeneous Lipolytic Activity. IOSR J Pharm Biol Sci 12(1): 105-114.

24. Bora L \& Kalita MC (2008). Production of thermostable alkaline lipase on vegetable oils from a thermophilic Bacillus sp. DH4, characterization and its potential applications as detergent additive. J Chem Technol Biotechnol 83: 688-693.

25. Lailaja VP \& Chandrasekaran M (2013). Detergent compatible alkaline lipase produced by marine Bacillus smithii BTMS 11. World J Microbiol Biotechnol 29:1349-1360.

26. Cherif S, Mnif S, Hadrich F, Abdelkaf S \& Sayadi S (2011). A newly high alkaline lipase: an ideal choice for application in detergent formulations. Lipids Health Dis 10: 221-228.

27. Sagar K, Bashir Y, Phukan MM \& Konwar BK (2013). Isolation of 
Lipolytic Bacteria From Waste Contaminated Soil: A Study With Regard To Process Optimization For Lipase. Int J Sci Technol Res 2(10): 214-218.

28. Sayari N, Agrebi S, Jaoua \& Gargouri Y (2001). Biochemical and molecular characterization of Staphylococcus simulans lipase. Biochimie 83:863-871.

29. Chauhan M, Chauhan RS \& Garlapati VK (2013). Evaluation of a New Lipase from Staphylococcus sp. for Detergent Additive Capability. J Biomed Biotechnol 2013:1-6

30. Asses N, Ayed L, Bouallagui H, Ben R, Gargouri I \& Hamdi M (2009). Use of Geotrichum candidum for olive mill wastewater treatment in submerged and static culture. Biores Technol 100: 2182-2188.

31. Odeyemi AT1, Aderiye BI \& Bamidele OS ((2013). Lipolytic Activity of some Strains of Klebsiella, Pseudomonas and Staphylococcus Spp. from Restaurant Wastewater and Receiving Stream. $J$ Microbiol Res 3(1): 43-52.
32. Mongkolthanaruk W \& Dharmsthiti S (2002). Biodegradation of lipid-rich waste water by a mixed bacterial consortium. Int Biodeterioration Biodegrad 50: 101-105.

33. Prasad MP \& Manjunath K (2011). Comparative study on Biodegradation of lipid-rich waste water using lipase producing bacterial species. Indian $J$ Biotechnol 10: 121-124.

34. Bhumibhamon O, Koprasertsak A \& Funthong S (2002). Biotreatment of High Fat and Oil Wastewater by Lipase Producing Microorganisms. Kasetsart J (Nat Sci) 36: $261-267$.

35. Brooksbank AM, Latchford JW \& Mudge SM (2007). Degradation and modification of fats, oils and grease by commercial microbial supplements. World J Microbiol Biotechnol

36. Ahmed HA, Gremos SS \& Kolisis FS (2010). Enzymatic Removal of the Oily Dirt from a Coptic Tunic using the Enzyme Lipase. J Text Appar Technol Manag 6(3):1-17. 